\title{
Evaluating The Perception of Climate Change Among Secondary School Science Teachers for Knowledge-Based Sustainable Development
}

\author{
Valentine E. Nnadi ${ }^{1 *} \quad$ Nkechi G. Nnoli ${ }^{1} \quad$ Ikenna C. Ezeasor $^{1} \quad$ Obiageli J. Okolo $^{1} \quad$ Violet U. Nnadi $^{2}$ \\ Ketanduoma N. Okorocha ${ }^{1}$ \\ 1. Shell Centre for Environmental Management \& Control (CEMAC), University of Nigeria, Enugu Campus, \\ 400241 Enugu State, Nigeria \\ 2. Institute for Development Studies University of Nigeria, Enugu Campus, 400241 Enugu State, Nigeria \\ *Corresponding author: valentine.nnadi@unn.edu.ng;ejour2020@gmail.com (V.E Nnadi) \\ https://orcid.org/0000-0003-2144-5853
}

\begin{abstract}
There appears to be lack of knowledge about the cause and effect of climate change amongst the secondary school students. This asks for evaluation of their source of knowledge in schools through the assessment of their teachers' knowledge and/or perception about climatic change. The survey research design was adopted and the perception of the secondary school science teachers' (SSSTs) evaluated using questionnaire. The results showed that SSSTs perception of human activities associated with climate change and the effects of human activities associated with climate is moderate. This was very clear when the grand mean responses of the teachers were found to be 2.81 and 2.61 respectively. The student $t$-test statistics used at $\mathrm{P}>0.05$ confirmed that there is no significant difference between the perception of urban and rural SSSTs on their perception of climate change. At $\mathrm{P}>0.05$, there is significant difference between experienced and less experienced SSSTs on their perception of climate change. The research concludes that there is knowledge gap in our secondary school educational system concerning climate change. Therefore, it recommends capacity building in science-teaching education curriculum for knowledge-based sustainable development.
\end{abstract}

Keywords: Curriculum, Global warming, Environmental Education, Greenhouse gases, Deforestation

DOI: $10.7176 / \mathrm{CER} / 13-5-03$

Publication date:August $31^{\text {st }} 2021$

\section{Introduction}

The wish of every nation is to resolve her social, economic, cultural and political problems and one of the ways of achieving this is through the right education or knowledge transfer. Knowledge is a key factor of development. Knowledge is key in the provision of social amenities, energy, transport and improved nutrition. Years before now, there were some forms of developments that did not consider the depreciating nature of the environment due to lack of knowledge and continued due partly to the demand on science and technology and increasing human population [1]. Little or nothing was talked about on educating the populace about the dangers of the depreciating environment because of lack of knowledge. As a result, social imbalance and the increase in poverty, the pollution of the soil, air and water, conflict between regions, the loss of expanses of forest, disease out breaks, flooding, erosion, drought, fire outbreaks and many more now became common environmental challenges to man. Research has shown that all these common environmental challenges are either responsible for the day-to-day climate change issues that we face today or that climate change is responsible for them [2].

According to the [3], climate change is as a result of unchecked pollution. It is a long-term change in weather conditions recognized by temperature change, rate of precipitation, wind speed and pattern, and other indicators $[4,5]$. Climate change can include the changes in average conditions as well as changes in variability, including, for instance, extreme events. Climate change is an extensive and long-lasting change in the statistical spreading of the weather pattern over a period of time within decades to millions of years [6]. It can be described as a change in average weather condition of a place, or weather distribution around the average conditions. These changes may be stirred by two fundamental agents: anthropogenic (human) and nature [2].

Climate of the Earth can be affected by natural influences that are external to the climate system, like changes in activity of volcanoes, solar output, and the Earth's orbit around the Sun. Changes in Solar radiation have contributed to climate trends for centuries but since the Industrial Revolution, the effect of greenhouse gases (GHGs) has multiplied about ten times that of changes in the Sun's output [7].

[8] state that climate change may as well be caused by human activities, most especially the combusting fossil fuels, intensive agriculture and land clearing, since the activities increase the concentrations of GHG in the lower atmosphere above natural levels. Given the advent of the Industrial Revolution, anthropogenic influences on the climate system have increased significantly. In addition to other environmental impacts, the activities alter the land surface and release several substances to the atmosphere. The overall effect of human activities has been a warming effect, driven mainly by carbon (iv) oxide emissions and boosted by emission of other GHGs. The accumulation 
of GHG in the atmosphere has led to an increase in effects of the natural GHGs. This human-induced enhancement of the GHG effect is of concern because on-going emissions of GHG have the potential to warm the planet to levels that have never been experienced in the history of human civilization. Such climate change may have extensive and/or erratic environmental, social, and economic consequences.

According to the [7], the first theory of climate change - anthropogenic global warming (AGW)- contends that human emissions of GHGs, predominantly carbon dioxide $\left(\mathrm{CO}_{2}\right)$, methane, and nitrous oxide, are causing catastrophic rise in global temperatures. The proponents of the AGW theory affirm that $\mathrm{CO}_{2}$ released due to anthropogenic activities is responsible for several floods, intense droughts, hash weather, crop failures and poor yield, species extinctions, disease spread, ocean coral bleaching, famines, and literally hundreds of other catastrophes. All these disasters occur frequently and severely as temperatures continually rise and seem to be occurring across all generations. The present generation of secondary school students appear to be so ignorant of cause(s) of these environmental challenges. Therefore, there is need for application of both short and long term rapid reduction strategies against human-induced environmental challenges to save the planet from these catastrophic events. One of the ways of doing this is through knowledge transfer. Therefore, this paper evaluates the perception of science teachers in secondary schools to know the level of flow of information in the society concerning climate change.

Several researches have been carried out to determine the perception of climate change among groups of people for sustainable development. Most of the findings of the researches revealed that people are moderately away of the causes of climate change and its effect in the environment. A study conducted in Great Britain (GB) in 2010 [9] reports that $47 \%$ of respondents felt that climate change was due to a combination of human activity and natural processes, with $24 \%$ perceiving it as mainly due to human activity and $7 \%$ felt that anthropogenic activity was completely responsible. [6] in a representative survey of the U.S. public found that Americans perceive the risk of climate change as being moderate in magnitude. The same study also found that Americans support several policies to mitigate climate change however, refute several proposals on carbon tax. [10] found that 47.4 per cent of the study population indicate that they agree or strongly agree with anthropogenic activities being the cause of recent changes in climate system. [11] in a study showed that 61 per cent of 2103 respondents perceived that the major cause of climate change was a combination of anthropogenic activity and natural processes; while 15 per cent of agreed that only natural processes was the major cause of climate change and 17 per cent perceived anthropogenic activity as the be solely responsible for climate change.

[12] in a study to identify and comprehend the perceptions of U.S agricultural producers concerning climate change, found that a majority of the farmers $(53 \%)$ did not imagine any noticeable change in climate for the next 20-30 years. In addition, 49 per cent of the farmers do not believe that global warming does exist. [13] surveyed a total population of 9500 farmers across ten countries in Africa and found that substantial number of farmers perceived average temperatures had increased. By contrast, almost none believed that the temperatures had decreased or that, apart from some farmers in Ethiopia. It was only in Cameroon that the people questioned perceived no change in temperatures than there had been an increase. A considerable minority also believed they had observed a change in the timing of the rainfall. Few of the farmers believed they had observed changes in the frequency of droughts, unlike in Senegal and Kenya where virtually all the participants believed they had observed the changes.

[11] in a study, found that sixty-one percent (61\%) of respondents perceived the main cause of climate change as a combination of anthropogenic activity and natural processes; while 15 per cent of respondents perceived natural processes alone to be the main cause of climate change and 17 per cent took anthropogenic activity to be solely responsible for climate change. A negligible number (3\%) of respondents did not believe in climate change. [14] in a study on 'Individual Perceptions of Climate Risks' reported that the reality of climate change is truly recognised in the international public opinion and mentioned that 9 out of 10 people polled accepted that the climate has changed considerably in the past 20 years. Although the effects of the change in climate are significantly becoming strong, it is never too late to do something about it. We must take action to slow its progress, even if it cannot be stopped entirely due to GHGs already in the atmosphere. Expectations is that every sector of the society in the world have to play a part in reducing the GHG emissions to circumvent the progressing climatic impacts and lessen the risk of making changes beyond human capacity to mitigate, respond and adapt. Developed nations have been making efforts to address this challenge through the adoption of policies to reduce energy use, limit GHG emissions, and create a clean energy economy [15]. Some climatic changes and impacts on the society are inevitable, even if we reduce GHG emissions today. Environmental problems such as climate change jeopardise our prosperity and our economic development. However, there may be a way to address it and more importantly on the basis of collaborative action and change of mind-sets. Just as humans cause climate change, we can halt its progress! By acting, we can significantly limit the effect and reduce the long-term costs of its related impacts which are expected to grow in number and intensity in the near future. However, to act, it is very important to understand socio-economic and ecological perceptions of the people. The major challenge countries therefore, face is to understand people's perception about the change in climate more especially in education setting since 
education is always seen as a propelling force for transfer of knowledge. For instance, [16] asserts that environmental education is a central aspect of the process of change towards sustainable development. It is time we understood that the environment is not just a factor in this game, rather it is a game in itself; such game that we all play in and on which our future existence depends.

This study therefore, specifically aims to determine the (1) Perception of human activities associated with climate change; (2) Perception of effects of human activities associated with climate change; (3) Influence of location on the perception of climate change; (4) Influence of teaching experience on the perception of climate change. It further raised four (4) research questions in line with the stated specific objectives. Based on this premise and literature reviewed, this present study evaluates the links between three main dimensions of causal effects in this study: human activities, location, and teaching experience on perception of climate change. Thus, the following null hypotheses are formulated:

$\boldsymbol{H}_{1}$ : There is no significant difference between urban and rural SSSTs in their perception of climate change.

$\boldsymbol{H}_{2}$ : Teaching experience exerts no significant influence on the perception of climate change among SSSTs.

This study may be useful on determining the need for incorporating environmental education, as a whole subject into the Nigerian secondary education curriculum, other than taking it as an integral part of other subjects for knowledge-based sustainable development.

\section{Methodology}

In this study, the survey research design was adopted and carried out in secondary schools in Enugu Education zone, Enugu State. Record from the Post Primary Schools Management Board (PPSMB) (2020) show that the total population of the SSSTs study comprised all the 641 SSSTs in all the secondary schools in Enugu Education Zone. Records from shows that while a total of 284 SSSTs are in Enugu East local government area, 251 are in Enugu north and 106 in Isi-uzo local government areas. Furthermore, while 118 SSSTs are in the rural area, 523 are in urban areas. The study population of 641 comprised the sample for the study. The entire population of SSSTs is studied because of the low numerical strength.

The instrument for data collection was the Perception of Climate Change Questionnaire (PCC-Q) designed by the researchers. There are three (3) sections of the instrument A, B and C made up of 18 items. The section $\mathrm{A}$ elicited information on the demographic background of the respondents. Sections B and C contains 7 and 9 items respectively, each with 4-point response options of Strongly Agree (SA); Agree (A); Disagree (D) and Strongly Disagree (SD). Each of the Sections B and C addressed research questions 1and 2 respectively, while research question 3 and 4 were answered by comparing the responses in $\mathrm{B}$ and $\mathrm{C}$ according to location and teaching experience.

The instrument was validated through the judgement of three (3) experts; one (1) from Science Education to be able to make input on climate change issues and its challenges. The other two (2) are experts in Measurement and Evaluation (Statistics) to be able to confirm the feasibility of Statistics modelling employed in the study. All the experts are from Enugu State University of Science and Technology, Enugu State, Nigeria. The experts were provided with purpose of the study, research questions, hypotheses and scope of the study as a guide. Their contributions were considered in producing the final copy of the questionnaire.

Reliability was established using the split-half method. Twenty copies of the questionnaire were administered to 20 SSSTs in Nsukka Education Zone. The responses were split into odd number and even number items. The scores from the two sets were correlated using the Cronbach alpha statistics. The correlation coefficient (r) index value yielded 0.75 showing that the instrument is reliable.

The researchers visited the schools in the education zone and administered the questionnaires personally to the respondents. The returned questionnaires were collated and inspected for completion. Out of the 641 copies of the questionnaire distributed, 473 were duly completed and therefore qualified for data analysis.

\section{Results}

Mean was used to analyse the data, while the student t-test statistics was employed in verifying the null hypothesis. The 4 response options of Strongly Agree (SA); Agree (A); Disagree (D) and Strongly Disagree (SD) were assigned values of 4, 3, 2 and 1 respectively. The mean scores of 3.50-4.00=high level, 2.50-3.49= moderate level, $1.00-2.49=$ low level was used. The t-test statistic was employed in verifying the two null hypotheses at .05 level of significance.

Research Question 1: What is the perception of human activities associated with climate change among SSSTs in Enugu Education Zone? Table 1 provides the answer to this research question. 
Table 1: Mean Rating of the SSSTs' Perception of Human Activities Associated with Climate Change (n=473)

\begin{tabular}{llll}
\hline S/N & Item Statements & Mean & Interpretation \\
\hline 3 & Automobile exhaust smokes contribute to climate change & 2.73 & Moderate Level \\
4 & Deforestation can cause climate change & 3.64 & High Level \\
5 & Bush burning causes climate change & 2.88 & Moderate Level \\
6 & Use of insecticide can cause climate change & 2.43 & Low Level \\
7 & Air Pollution causes global climate change & 2.91 & Moderate Level \\
8 & Gas emissions from oil-producing companies contributes to & 2.78 & Moderate Level \\
& climate change & 2.32 & Low Level \\
9 & Use of herbicides causes climate change & & \\
& & $\mathbf{2 . 8 1}$ & Moderate Level \\
\hline
\end{tabular}

Results in table 1 above, show that response to items 3, 5, 7 and 8 with mean scores of 2.73, 2.88, 2.91 and 2.78 respectively observe moderate level of human activities associated with climate change. Again, item 4 with mean score of 3.64 observe high level of human activities associated with climate change. However, items 6 and 9 observed low level of human activities associated with climate change. A grand mean of 2.81 was computed for the entire items of 3-9.

Research Question 2: What is the perception of effects of human activities associated with climate change among SSSTs in Enugu Education Zone? Table 2 provides the answer to this research question.

Table 2: Mean Rating of the SSSTs' Perception of the Effects of Human Activities Associated with Climate Change $(\mathrm{n}=473)$.

\begin{tabular}{lllc}
\hline S/N & Items Statement & Mean & Interpretation \\
\hline 10 & Climate change can cause bush fire outbreaks. & 1.99 & Low Level \\
11 & Climate change can cause rapid transpiration in plants. & 2.61 & \multicolumn{1}{c}{ Moderate Level } \\
12 & Climate change brings about low productivity in agricultural crops. & 3.58 & High Level \\
13 & Climate change can cause skin burn due to high sunlight intensity & 3.08 & Moderate Level \\
& that we face today. & & \\
14 & $\begin{array}{l}\text { Climate change causes hunger and lack of drinking water. } \\
\text { Climate change is responsible for the change in rainfall patterns }\end{array}$ & 2.65 & Low Level \\
& $\begin{array}{l}\text { in the last 20 years. } \\
\text { Climate change is responsible for the recurring annual }\end{array}$ & 2.72 & Moderate Level \\
16 & $\begin{array}{l}\text { flooding being heavier than they used to be. } \\
\text { Climate change can cause drought. }\end{array}$ & 2.46 & Low Level \\
18 & Climate change can cause change in crop growing season & 2.68 & Moderate Level \\
& Grand Mean & $\mathbf{2 . 6 9}$ & Moderate Level \\
\hline
\end{tabular}

From Table 2 above, items 10, 14 and 17 with mean scores of 1.99, 2.42 and 2.46 respectively indicates that SSSTs observe low level of the effects of human activities associated with climate change. Items 11, 13, 15, 16 and 18 with mean scores of 2.61, 3.08, 2.65, 2.72 and 2.68 observes high level of human activities associated with climate change. However, item 12 observes high level of human activities associated with climate change. A grand mean of 2.69 was computed for the entire items 10-18.

Research Question 3: What is the Influence of location on the perception of climate change among SSSTs in Enugu Education Zone? 
Table 3: Mean Rating of the SSSTs' Response on the Influence of Location on the Perception of Climate Change (Urban=371 and Rural=102).

\begin{tabular}{|c|c|c|c|c|c|}
\hline $\mathbf{S} / \mathbf{N}$ & Item Statements & Location & Mean & SD & Interpretation \\
\hline \multirow[t]{2}{*}{3} & Automobile exhaust smokes contribute to climate change & $\mathrm{U}$ & 2.92 & 1.12 & Moderate Level \\
\hline & & $\mathrm{R}$ & 3.00 & 1.10 & Moderate Level \\
\hline \multirow[t]{2}{*}{4} & Deforestation can cause climate change & $\mathrm{U}$ & 2.06 & 1.10 & Low Level \\
\hline & & $\mathrm{R}$ & 1.99 & 1.05 & Low Level \\
\hline \multirow[t]{2}{*}{5} & Bush burning causes climate change & $\mathrm{U}$ & 2.45 & 1.11 & Low Level \\
\hline & & $\mathrm{R}$ & 2.29 & 1.16 & Low Level \\
\hline \multirow[t]{2}{*}{6} & Use of insecticide can cause climate change & $\mathrm{U}$ & 3.07 & 1.04 & Moderate Level \\
\hline & & $\mathrm{R}$ & 2.69 & 1.17 & Moderate Level \\
\hline \multirow[t]{2}{*}{7} & Air Pollution causes global climate change & $\mathrm{U}$ & 3.19 & 0.97 & Moderate Level \\
\hline & & $\mathrm{R}$ & 3.01 & 1.00 & Moderate Level \\
\hline \multirow[t]{2}{*}{8} & $\begin{array}{l}\text { Gas emissions from oil-producing companies contributes } \\
\text { to climate change }\end{array}$ & $\mathrm{U}$ & 3.55 & 1.12 & High Level \\
\hline & & $\mathrm{R}$ & 3.59 & 1.10 & High Level \\
\hline \multirow[t]{2}{*}{9} & Use of herbicides causes climate change & $\mathrm{U}$ & 3.80 & 0.71 & High Level \\
\hline & & $\mathrm{R}$ & 3.34 & 0.97 & Moderate Level \\
\hline \multirow[t]{2}{*}{10} & Climate change can cause bush fire outbreaks. & $\mathrm{U}$ & 3.15 & 0.97 & Moderate Level \\
\hline & & $\mathrm{R}$ & 3.04 & 1.05 & Moderate Level \\
\hline \multirow[t]{2}{*}{11} & Climate change can cause rapid transpiration in plants & $\mathrm{U}$ & 3.05 & 0.93 & Low Level \\
\hline & & $\mathrm{R}$ & 2.80 & 1.05 & \\
\hline \multirow[t]{2}{*}{12} & $\begin{array}{l}\text { Climate change brings about low productivity in } \\
\text { agricultural crops. }\end{array}$ & $\mathrm{U}$ & 2.04 & 0.88 & Low Level \\
\hline & & $\mathrm{R}$ & 2.09 & 0.92 & Low Level \\
\hline \multirow[t]{3}{*}{13} & $\begin{array}{l}\text { Climate change can cause skin burn due to high sunlight } \\
\text { intensity that we face today. }\end{array}$ & $\mathrm{U}$ & 1.75 & 0.86 & Low Level \\
\hline & & $\mathrm{R}$ & 1.92 & 1.10 & Low Level \\
\hline & Table 3 Continued & & & & \\
\hline \multirow[t]{2}{*}{14} & Climate change causes hunger and lack of drinking & $\mathrm{U}$ & 3.31 & 1.02 & Moderate Level \\
\hline & water. & $\mathrm{R}$ & 2.87 & 1.01 & Moderate Level \\
\hline \multirow[t]{2}{*}{15} & $\begin{array}{l}\text { Climate change is responsible for the change in rainfall } \\
\text { patterns in the last } 20 \text { years. }\end{array}$ & $\mathrm{U}$ & 2.92 & 1.12 & Moderate Level \\
\hline & & $\mathrm{R}$ & 3.00 & 1.10 & Moderate Level \\
\hline \multirow[t]{2}{*}{16} & $\begin{array}{l}\text { Climate change is responsible for the recurring annual } \\
\text { flooding being heavier than they used to be. }\end{array}$ & $\mathrm{U}$ & 2.92 & 0.91 & Moderate Level \\
\hline & & $\mathrm{R}$ & 3.01 & 0.89 & Moderate Level \\
\hline \multirow[t]{2}{*}{17} & Climate change can cause drought. & $\mathrm{U}$ & 2.01 & 1.03 & Low Level \\
\hline & & $\mathrm{R}$ & 2.87 & 1.01 & Moderate Level \\
\hline \multirow[t]{4}{*}{18} & $\begin{array}{l}\text { Climate change can cause change in crop growing } \\
\text { seasons. }\end{array}$ & $\mathrm{U}$ & 2.46 & 0.87 & Low Level \\
\hline & & $\mathrm{R}$ & 3.02 & 1.01 & Moderate Level \\
\hline & Grand Mean and Standard Deviation & $\mathbf{U}$ & 2.79 & 1.04 & Moderate Level \\
\hline & & $\mathbf{R}$ & 2.78 & 1.1 & Moderate Level \\
\hline
\end{tabular}

\footnotetext{
Key: $U=$ Urban

$R=$ Rural
}

The table 3 above shows the different response of urban and rural SSSTs concerning the influence of location on their perception of climate change. The greater responses in the whole items except items 9,17 and 18, shows that both urban and rural SSSTs share the same perception about climate change. Item 9 with mean rate of 3.80 and 3.34 for urban and rural SSSTs respectively indicate that urban SSSTs observe high level on their perception of the use of herbicides causing climate change while rural SSSTs observe moderate level on their perception of the use of herbicides causing climate change. Item 17 with mean rate of 2.01 and 2.87 for urban and rural SSSTs respectively shows that urban SSSTs observe low level while rural SSSTs observe moderate level on their 
perception of climate change being able to cause drought. In item 18, the mean rates of urban and rural SSSTs are 2.46 and 3.02 respectively. This shows that urban SSSTs observe low level while rural SSSTs observe moderate level on their perception of climate change being able to cause change in crop growing seasons. The grand mean which is 2.79 and 2.78 for urban and rural SSSTs respectively indicates that both groups observe the same level of (moderate level) on their perception of climate change.

Research Question 4: What is the Influence of teaching experience on the perception of climate change among SSSTs in Enugu Education Zone?

Table 4: Mean Rating of the SSSTs' Response on the Influence of Teaching Experience on the Perception of Climate Change (Experienced=297 and Less Experienced=176).

\begin{tabular}{|c|c|c|c|c|c|}
\hline $\mathbf{S} / \mathbf{N}$ & Item Statements & Experience & Mean & SD & Interpretation \\
\hline \multirow[t]{2}{*}{3} & $\begin{array}{l}\text { Automobile exhaust smokes contribute } \\
\text { climate change }\end{array}$ & $\mathrm{E}$ & 3.02 & 1.11 & Moderate Level \\
\hline & & $\mathrm{L}$ & 2.89 & 1.11 & Moderate Level \\
\hline \multirow[t]{2}{*}{4} & Deforestation can cause climate change & $\mathrm{E}$ & 3.87 & 2.00 & High Level \\
\hline & & $\mathrm{L}$ & 2.17 & 1.15 & Low Level \\
\hline \multirow[t]{2}{*}{5} & Bush burning causes climate change & $\mathrm{E}$ & 3.09 & 1.12 & Moderate Level \\
\hline & & $\mathrm{L}$ & 2.83 & 1.14 & Moderate Level \\
\hline \multirow[t]{2}{*}{6} & Use of insecticide can cause climate change & $\mathrm{E}$ & 3.52 & 1.02 & High Level \\
\hline & & $\mathrm{L}$ & 2.48 & 1.19 & Low Level \\
\hline \multirow[t]{2}{*}{7} & Air Pollution causes global climate change & $\mathrm{E}$ & 3.87 & 0.84 & High Level \\
\hline & & $\mathrm{L}$ & 3.58 & 1.05 & High Level \\
\hline \multirow[t]{2}{*}{8} & $\begin{array}{l}\text { Gas emissions from oil-producing companies } \\
\text { contributes to climate change }\end{array}$ & $\mathrm{E}$ & 3.69 & 0.62 & High Level \\
\hline & & $\mathrm{L}$ & 3.42 & 0.92 & Moderate Level \\
\hline \multirow[t]{2}{*}{9} & Use of herbicides causes climate change & $\mathrm{E}$ & 2.71 & 0.64 & Moderate Level \\
\hline & & $\mathrm{L}$ & 3.64 & 0.91 & Moderate Level \\
\hline \multirow[t]{2}{*}{10} & Climate change can cause bush fire outbreaks. & $\mathrm{E}$ & 3.16 & 1.02 & Moderate Level \\
\hline & & $\mathrm{L}$ & 2.96 & 1.00 & Moderate Level \\
\hline \multirow[t]{2}{*}{11} & $\begin{array}{l}\text { Climate change can cause rapid transpiration in } \\
\text { plants }\end{array}$ & $\mathrm{E}$ & 3.48 & 0.86 & Moderate Level \\
\hline & & $\mathrm{L}$ & 2.66 & 1.90 & Moderate Level \\
\hline \multirow[t]{2}{*}{12} & $\begin{array}{l}\text { Climate change brings about low productivity in } \\
\text { agricultural crops. }\end{array}$ & $\mathrm{E}$ & 2.01 & 0.96 & Low Level \\
\hline & & $\mathrm{L}$ & 2.07 & 1.02 & Low Level \\
\hline \multirow[t]{2}{*}{13} & $\begin{array}{l}\text { Climate change can cause skin burn due to high } \\
\text { sunlight intensity that we face today. }\end{array}$ & $\mathrm{E}$ & 3.57 & 1.10 & Low Level \\
\hline & & $\mathrm{L}$ & 1.81 & 1.05 & Low Level \\
\hline \multirow[t]{2}{*}{14} & $\begin{array}{l}\text { Climate change causes hunger and lack of } \\
\text { drinking water. }\end{array}$ & $\mathrm{E}$ & 3.43 & 0.88 & Moderate Level \\
\hline & & $\mathrm{L}$ & 2.78 & 1.10 & Moderate Level \\
\hline \multirow[t]{2}{*}{15} & $\begin{array}{l}\text { Climate change is responsible for the change in } \\
\text { rainfall patterns in the last } 20 \text { years. }\end{array}$ & $\mathrm{E}$ & 3.50 & 0.92 & High Level \\
\hline & & $\mathrm{L}$ & 2.52 & 1.02 & Moderate Level \\
\hline \multirow[t]{2}{*}{16} & $\begin{array}{l}\text { Climate change is responsible for the recurring } \\
\text { annual flooding being heavier than they used to } \\
\text { be. }\end{array}$ & $\mathrm{E}$ & 2.75 & 0.89 & Moderate Level \\
\hline & & $\mathrm{L}$ & 2.64 & 0.94 & Moderate Level \\
\hline \multirow[t]{2}{*}{17} & Climate change can cause drought. & $\mathrm{E}$ & 3.42 & 1.03 & Moderate Level \\
\hline & & $\mathrm{L}$ & 2.81 & 1.10 & Moderate Level \\
\hline \multirow[t]{4}{*}{18} & Climate change can cause change in crop growing & $\mathrm{E}$ & 3.69 & 1.16 & High Level \\
\hline & seasons. & $\mathrm{L}$ & 2.85 & 1.09 & Moderate Level \\
\hline & Grand Mean and Standard Deviation & $\mathbf{E}$ & 3.30 & 1.01 & Moderate Level \\
\hline & & $\mathbf{L}$ & 2.76 & 1.10 & Moderate Level \\
\hline
\end{tabular}

Note: $E=$ Experienced (11 years and above) $L=$ Less experienced (10 years and below) 
Table 4 above shows varying responses of SSSTs with different years of experience. Their perceptions of climate change are the same except for items 4, 6, 8, 15 and 18 where SSSTs with 11 years and above experience have high perception compared to the less experienced (10 years and below). In item 4, experienced SSSTs with mean rate of 3.87 observe high level of deforestation being able to cause climate change while those with less experience and mean rate of 2.17 observe low level of perception on deforestation being able to cause climate change. The experienced SSSTs with mean value of 3.52 is observed to be high when compared to less experienced with mean value of 2.48 observed as being low. In items 8,15 and 18, the 11 years and above experienced SSSTs with mean rates of 3.69, 3.50 and 3.69 respectively observe high level while 10 years and below with mean rates of $3.42,2.52,2.85$ observe moderate level on perception of climate change. The grand mean computed gave a mean of 2.79 and 2.78 for experienced and less experience respectively.

\section{Hypothesis 1}

There is no significant difference between urban and rural SSSTs in Enugu Education Zone on their perception of climate change.

Table 6: Summary of the t-test Analysis Verifying the Difference between Urban and Rural SSSTs on their Perception of Climate Change

\begin{tabular}{lcccccccc}
\hline Location & $n$ & Mean & $S D$ & $d f$ & $t$-cal & $t$-critical & $P$ & Decision \\
\hline Urban & 297 & 2.79 & 1.04 & 238 & 0.90 & 1.96 & 0.05 & Accepted \\
Rural & 176 & 2.78 & 1.10 & & & & & \\
\hline Signifant at $P>0.05$ & & & & & &
\end{tabular}

Significant at $P>0.05$

Table 6 above shows that the $t$-cal $(0.90)$ is less than the t-critical (1.96). Therefore, the null hypothesis which states that, there is no significant difference between urban and rural SSSTs in Enugu Education Zone on their perception of climate change is accepted and the alternative rejected.

\section{Hypothesis 2}

There is no significant difference between experienced and less experienced SSSTs in Enugu Education Zone on their perception of climate change.

Table 7: Summary of the t-test Analysis Verifying the Difference between Experienced and Less Experienced SSSTs on their Perception of Climate Change

\begin{tabular}{lcccccccl}
\hline Experience & $n$ & Mean & $S D$ & $d f$ & $t$-cal & $t$-critical & $P$ & Decision \\
\hline Experienced & 169 & 3.30 & 1.01 & 238 & 2.26 & 1.96 & 0.05 & Rejected \\
Less Experienced & 304 & 2.76 & 1.10 & & & & & \\
\hline
\end{tabular}

Significant at $P>0.05$

Table 7 above shows that $t$-cal (2.26) is greater than t-critical (1.96). Therefore, the null hypothesis which states that there is no significant difference between experienced and less experienced SSSTs in Enugu Education Zone on their perception of climate change is rejected and the alternative accepted.

\section{Discussion}

The findings in research question one shows that SSSTs moderately perceive that automobile exhaust smokes, bush burning, air pollution and gas emissions from oil-producing companies contributes to climate change. This could be attributed to the knowledge they have about the causes of climate change. From the literature reviewed, this finding is in line with $[10,11]$. However, the findings show high level of perception on deforestation being able to cause climate change. This is also attributed to the SSSTs high knowledge of the effects of deforestation. The findings show low perception on the use of insecticide as being able to cause climate change and could be attributed to their poor knowledge of the effects of insecticide.

The findings in research question two shows that SSSTs have low perception on climate change being able to cause bush fire outbreaks and climate change being able to cause hunger, lack of drinking water and drought. This may be attributed to the fact that they lack the knowledge of the effects of climate change. However, this is contrary to [9] where half of the respondents $(50 \%)$ who believed in climate change were concerned about the possible impacts of climate change in Northern Ireland. Moreover, climate change is perceived moderately on being able to cause rapid transpiration in plants; skin burn in humans due to high sunlight intensity that we face today; change in rainfall patterns in the last 20 years. Ratings was also moderate in perceiving climate change as being responsible for the recurring annual flooding and being heavier than they used to be and again, climate change affecting crop growing seasons. This indicates that the SSSTs knowledge about the effects of climate change is moderate. These findings support $[13,14]$ as reviewed in literature. The findings also revealed perception of climate change to be high on bringing about low productivity in agricultural crops. It is due to the fact that the SSSTs have a higher knowledge of climate change bringing about low productivity in agricultural crops. This refutes the North Carolina producers surveyed [10] where 18.3 per cent believe that climate change will decrease average yields by 5 per cent or more over the next 25 years.

In research question three, it is found that teaching experience of the SSSTs' influences their perception of climate change. This may be due to the fact that, if someone's knowledge about climate change is increased over 
a long period of time, it could positively influence his/her understanding of the concept(s). In other words, if the SSSTs' knowledge about causes and effects of climate change is increased over a long period of time through programmes or integration in curriculum, perception could be positively influenced to a high level. This, in turn will give them the ground for passing it on to the students in their teaching activities because the language is "garbage-in garbage-out". We cannot give what we do not have. Nevertheless, low level of perception may be due to inadequate information or ignorance of the SSSTs. Though, some of them may not have been taught anything about climate change, they also contribute by not widening their knowledge.

Again, in research question four, location has no influence on SSSTs' perception on climate change. This refutes the [11] which reported that there are some significant differences in the concerns of respondents depending on whether they live in urban or rural areas. Respondents from urban areas are more concerned about a more polluted atmosphere and economic instability; whilst rural respondents are more concerned than their urban counterparts about the impacts on agricultural production. Meanwhile, observing high perception of climate change is attributed to the knowledge the SSSTs have on climate change irrespective of their locations.

\section{Conclusion and Recommendations}

The overall findings of this study indicate a gap in the secondary school educational system concerning their knowledge of climate change for knowledge-based sustainable development. Therefore, we conclude that the knowledge of climate change is not adequate in the science teachers' education curriculum and invariably lacking in secondary school students since one cannot give what he/she does not have. Based on the findings of this research, the following recommendations are made;

1. Continuous climate change initiative programmes such as seminars, trainings and workshops should be organized where causes, effects and the way forward for climate change should be made known to the teachers.

2. Effort should be made to ensure that Ministry of Environment, Ministry of Education and other related ministries and government agencies and parastatals collaborate with schools in a bid to establishing climate change initiative centres in schools for in-house training of teachers.

3. Environmental education with the key elements of climate change should be made a whole subject in science teacher curriculum and not an integral part of other subjects such as Civic education, Geography, Agricultural science and some others.

4. Environmental education when made a whole subject should be made compulsory for students so as to have introductory knowledge of climate change, its cause and effect. This is because, it is time we realised that the environment is not just a factor in this game we play on planet earth, instead it a game in itself which everyone should participate in for sustainable development and our future existence.

\section{References}

[1] Nnadi V. E, Okolo O. J, Ezeasor I. C, Nnoli N. G, Okenwa S. E (2021). Assessment of the Implications of Coal Post-mining Impact on Surface Water at Abandoned Okpara mine in Enugu State. Journal of Environment and Earth Science, Vol.11, No.4, 2021ISSN (Paper)2224-3216 ISSN (Online)2225-0948.

[2] National Oceanic and Atmospheric Administration (NOAA) (2010): Earth System Research Laboratory, “'Ongoing Scientific Assessment of the Western Russian Heat Wave of 2010".

[3] Proceedings of the National Academy of Sciences (2012). "Perception of Climate Change'. [Online]; Available at: http://www.ecy.wa.gov/climatechange/whatis.htm. Accessed 6th January, 2014

[4] Barring L. (1993). Climate - Change or variation? Climate Change 25: 1-13

[5] Pielke R. Jr (2004). What is Climate Change? Issues in Science and Technology Summer 2004. PP 1-4

[6] Leiserowitz A. (2006). Climate Change Risk Perception and Policy Preferences: The Role of Affect, Imagery, and Values. Climate Change 77(1):45-72

[7] Intergovernmental Panel on Climate Change (IPCC) (2007). The Physical Science Basis Summary for Policymakers Contribution of Working Group I to the Fourth Assessment Report of the Intergovernmental Panel on Climate Change Paris, February 2007. [Online]; Available at: http://www.ipc.ch Accessed $10^{\text {th }}$ January, 2014

[8] Levina E., Jacob J.S., Ramos L.E and Ortiz I. (2007). Policy Frameworks for Adaptation to Climate Change in Coastal Zones: The Case of the Gulf of Mexico, OECD/IEA. [Online]; Available at: www.oecd.org/bookshop Accesed 31st December 2013.

[9] PPCC (2010). Public Perceptions of Climate Change and Energy in Britain.

[10] Roderick M.R (2009). Farmer Perceptions and Beliefs about Climate Change: A North Carolina Perspective. WIRES Climate Change 1: 332-342

[11] Scottish Environmental Attitudes and Behaviours Survey (2008). Public Perceptions on Climate Change in North Ireland, Scotland 2012. [Online]; Available at: http://www.scotland.gov.uk/Topics/Research/bytopic/environment/social-research/Environmental-Attitudes. Accessed I ${ }^{\text {st }}$ Feb. 2014.

[12] Weber E. U. (1997). Perception and Expectation of Climate Change: Precondition for Economic and 
Technological Adaptation, in M.H Bazerman, D.M Climate Change Bulletin, 15, 271-357

[13] Maddison D (2007). The World Bank Development Research Group Sustainable Rural and Urban Development Team. Policy Research Working Paper 4308.

[14] Survey AXA/IPSOS (2012). Individual Perceptions of climate risks. Direction of Communications and Corporate Responsibility - Corporate Communications and Group Risk Management, USA

[15] Intergovernmental Panel on Climate Change (IPCC) (2001a). Climate Change 2001: Summary for Policymakers, A contribution of Working Groups I, II and III to the Third Assessment Report of the intergovernmental Panel on Climate Change. [Watson R T and the Core Writing Team (eds.)], Cambridge: Cambridge University Press.

[16] Leiserowitz A (2008). Public Perception, Opinion and Understanding of Climate-Current Patterns, Trends and Limitations. Human Development Report 2007/2008. Available online at: http://hdr.undp.org/en/reports/global/hdr2007-2008/papaers/leiserowitz_anthony.pdf (Accessed 0n 24th December 2013). 